\title{
Interannual variability in timing of bloom initiation in the California Current System
}

\author{
Stephanie A. Henson ${ }^{1}$ and Andrew C. Thomas ${ }^{1}$ \\ Received 10 October 2006; revised 1 March 2007; accepted 13 April 2007; published 9 August 2007.
}

[1] In the California Current System the spring transition from poleward to equatorward alongshore wind stress heralds the beginning of upwelling-favorable conditions. The phytoplankton response to this transition is investigated using 8 years (1998-2005) of daily, 4-km resolution, Sea-viewing Wide Field of view Sensor (SeaWiFS) chlorophyll $a$ concentration data. Cluster analysis of the chlorophyll $a$ time series at each location is used to separate the inshore upwelling region from offshore and oligotrophic areas. An objective method for estimating the timing of bloom initiation is used to construct a map of the mean bloom start date. Interannual variability in bloom timing and magnitude is investigated in four regions: $45^{\circ} \mathrm{N}-50^{\circ} \mathrm{N}, 40^{\circ} \mathrm{N}-45^{\circ} \mathrm{N}, 35^{\circ} \mathrm{N}-40^{\circ} \mathrm{N}$ and $20^{\circ} \mathrm{N}-35^{\circ} \mathrm{N}$. Daily satellite derived wind data (QuikSCAT) allow the timing of the first episode of persistently upwelling favorable winds to be estimated. Bloom initiation generally coincides with the onset of upwelling winds ( \pm 15 days). South of $\sim 35^{\circ} \mathrm{N}$, where winds are southward year-round, the timing of increased chlorophyll concentration corresponds closely to timing of the seasonal increase in upwelling intensity. A 1-D model and satellite derived photosynthetically available radiation data are used to estimate time series of depth-averaged irradiance. In the far north of the region $\left(>46^{\circ} \mathrm{N}\right)$ light is shown to limit phytoplankton growth in early spring. In 2005 the spring bloom in the northern regions $\left(>35^{\circ} \mathrm{N}\right)$ had a "false start". A sharp increase in chl $a$ in February quickly receded, and a sustained increase in biomass was delayed until July. We hypothesize that this resulted in a mismatch in timing of food availability to higher trophic levels.

Citation: Henson, S. A., and A. C. Thomas (2007), Interannual variability in timing of bloom initiation in the California Current System, J. Geophys. Res., 112, C08007, doi:10.1029/2006JC003960.

\section{Introduction}

[2] The California Current System (CCS), extending from British Columbia to Baja California, is typical of an eastern boundary current system (Figure 1). The region encompasses an equatorward surface flow which transports cold, relatively fresh water from the subarctic Pacific [Hickey, 1998]. As the coastline is oriented roughly north-south, poleward winds result in downwelling conditions at the coast, while equatorward winds lead to offshore Ekman transport of surface water and subsequent upwelling. The seasonal variation in the dominant winds varies latitudinally [Bakun and Nelson, 1991]. In the southern regions of the CCS (south of $\sim 35^{\circ} \mathrm{N}$ ), alongshore wind stress is upwelling-favorable year-round. At higher latitudes the winds are predominantly poleward in winter, changing in spring to a consistently southward direction. The shift to upwelling-favorable conditions occurs rapidly over the course of a few days, typically during March or April, and is commonly referred to as the spring transition [Huyer et al., 1979]. The onset of persistent equatorward winds is

${ }^{1}$ School of Marine Sciences, University of Maine, Orono, Maine, USA.

Copyright 2007 by the American Geophysical Union. 0148-0227/07/2006JC003960\$09.00 accompanied by a drop in coastal sea levels [Strub et al., 1987a; Strub and James, 1988]. Cold, subsurface, nutrientrich water is upwelled over the shelf, resulting in elevated phytoplankton biomass and primary production [Thomas and Strub, 1989].

[3] The spatial and temporal patterns of surface biological variability are well characterized by the repeated, synoptic satellite imagery of chlorophyll concentration. The mean seasonal cycle of biomass in the CCS consists of a widespread bloom, which occurs shortly after the onset of upwelling in early spring [Thomas et al., 1994]. Inshore, a sharp frontal gradient, coincident with the coastal jet, forms rapidly [Strub et al., 1990]. A diffuse region of elevated chlorophyll concentration spreads offshore during autumn, before low winter concentrations are established [Strub and James, 2000].

[4] As a successful growth season in this region depends on specific meteorological conditions, interannual variability in physical forcing has the potential to impact heavily on productivity. Indeed, biological response at several trophic levels to El Niño-Southern Oscillation and interdecadal variability has been documented [Batchelder and Powell, 2002, and references therein] El Niño conditions in the CCS are typically expressed as warm SST, elevated coastal sea level, reduced upwelling and poor biological productivity 


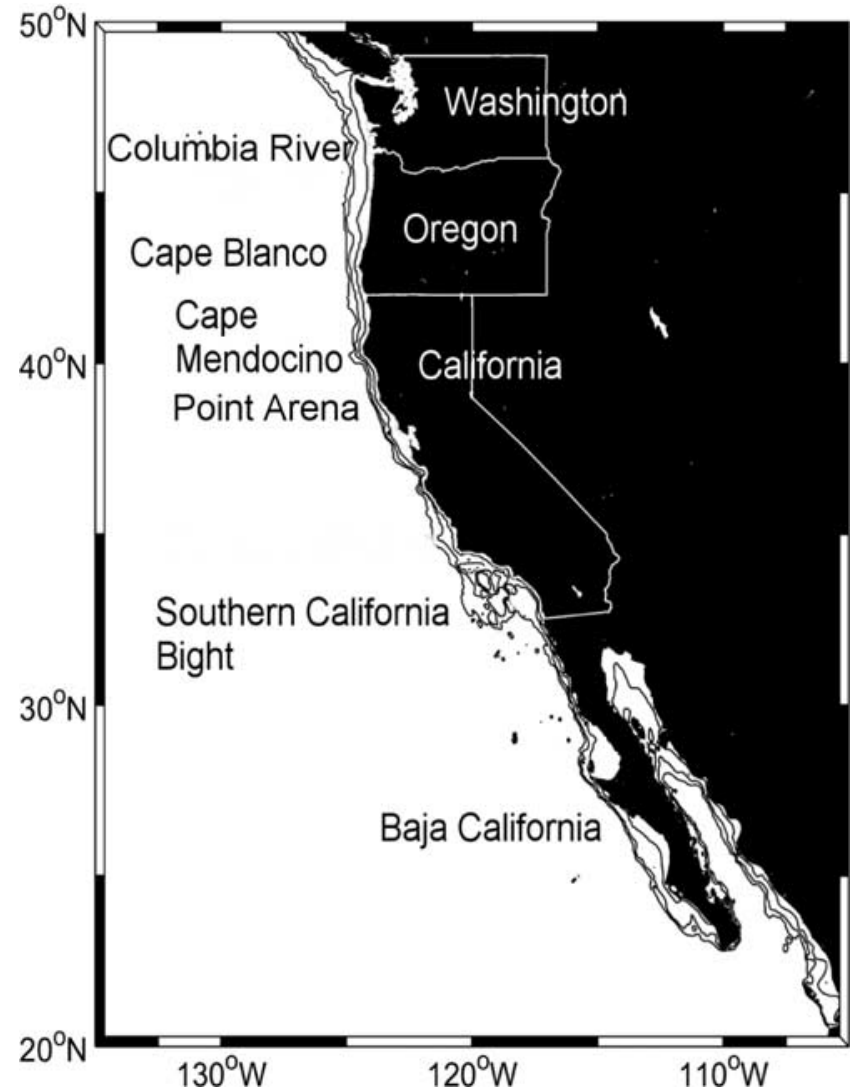

Figure 1. Map of the study region showing locations mentioned in the text. Bathymetric contours are at 100, 500, and $1000 \mathrm{~m}$.

[Hickey, 1998; Lynn et al., 1998], and vice versa in La Niña years.

[5] Statistics of sea surface temperature (SST) and chlorophyll data suggest that phytoplankton generally behave as passive tracers of physical processes in the CCS [Smith et al., 1988; Denman and Abbott, 1994]. Coastal Zone Color Scanner (CZCS) data from central California demonstrate that phytoplankton pigment patterns respond rapidly to variations in wind-forcing [Abbott and Barksdale, 1991]. Pigment distribution is often correlated with alongshore wind stress and wind mixing, although this varies with location and season [Strub et al., 1990; Thomas and Strub, 1989, 2001]. Unfortunately, the restrictions and inaccuracies of the CZCS instrument confined earlier studies to, at best, 10-day composite images, only a few years of coverage and latitudes south of $\sim 45^{\circ} \mathrm{N}$. Here 8 years of daily SeaWiFS chlorophyll $a$ concentration and 6 years of high-resolution, daily QuikSCAT wind data provide a systematic and synoptic view of the relationship between wind-forcing and phytoplankton response during spring in the California Current System.

\section{Methods}

[6] Daily level-2 global area coverage SeaWiFS chlorophyll $a$ data (chl $a$ ) processed with OC5.1 NASA global coefficients were obtained from the Goddard Space Flight Center Distributed Active Archive Center (http:// oceancolor.gsfc.nasa.gov/). All daily data from 1998-2005 were subsampled over the California Current region $\left(20^{\circ} \mathrm{N}\right.$ to $55^{\circ} \mathrm{N}, 135^{\circ} \mathrm{W}$ to $105^{\circ} \mathrm{W}$ ) and regridded to a standard projection at $4 \mathrm{~km}$ resolution. Climatological time series were calculated by averaging daily values of the 8 years of log-transformed chl $a$ at each pixel. Monthly composites were similarly constructed from the mean of log-transformed chl $a$. Prior to further analysis, data were backtransformed to a linear scale. Daily L3 mapped SeaWiFS PAR data at $9 \mathrm{~km}$ resolution were also obtained from the GSFC-DAAC, regridded to $0.25^{\circ}$ resolution. For direct comparison with Riley's [1957] compensation irradiance, data were converted from Einstein's $\mathrm{m}^{-2}$ day $^{-1}$ to $\mathrm{W} \mathrm{m}^{-2}$ by the equation of Morel and Smith [1974].

[7] Daily scatterometer (QuikScat) data at $0.25^{\circ}$ resolution from mid-July 1999 to 2005 were acquired from Remote Sensing Systems (http://www.ssmi.com/). Alongshore wind stress was calculated from the wind vectors. Daily, $2^{\circ}$ resolution wind vector data for the years prior to QuikSCAT (1998 and 1999) were supplied by the NCEP/ NCAR reanalysis project (www.cdc.noaa.gov).

[8] A 1-D vertical mixing model was used to estimate mixed layer depth. The model uses a Kraus and Turner [1967] mixing scheme; details of the model are given by Waniek [2003]. Inputs to the model are daily values of air temperature, net shortwave radiation, relative humidity and cloud cover (all from the NCEP/NCAR reanalysis project) and wind speed (QuikSCAT data for 2000-2005, NCEP/ NCAR data for 1998 and 1999). For the years 1999-2005 the model was initialized with temperature and salinity profiles measured by Argo floats in January of each year between $20^{\circ} \mathrm{N}$ and $55^{\circ} \mathrm{N}$, in water depths greater than $500 \mathrm{~m}$ and within $\sim 250 \mathrm{~km}$ of the coast (data available from http:// www.coriolis.eu.org/). Suitable Argo data were not available in 1998 and instead the model was initialized using a CTD profile taken in January 1998 on a Line-P cruise (station P4 at $48^{\circ} \mathrm{N}$ http://www.pac.dfo-mpo.gc.ca/). A temperature difference from the surface of $0.05^{\circ} \mathrm{C}$ was used to estimate the mixed layer depth. This simple model does not account for the effects of advection, freshwater input or upwelling of cold, saline water.

[9] We objectively define the spatial extent of the coastal region influenced by upwelling based on the temporal variability of chl $a$ using k-means cluster analysis. Cluster analysis sorts objects (in this case chl $a$ pixel values) into different groups such that the degree of association between two objects is maximal if they belong to the same group and minimal otherwise. As applied to this study, the cluster analysis attempts to define geographical regions which encompass similar temporal behavior of chl $a$. Squared Euclidean distance is used as the metric of separation. The cluster analysis was performed both on monthly composites of the 8-year climatological chlorophyll a time series, and separately for each year 1998-2005. The optimum number of clusters was found to be four, on the basis of silhouette values (see Kaufman and Rousseeuw [1990] for details) (but note that one of these clusters is the land, which is assigned a value of zero).

[10] Daily time series of chl $a$ data at each pixel are used to estimate the timing of the first period of substantial and sustained increase in chlorophyll above winter levels. This is calculated as the first day that chl $a$ rises 5\% above the annual median and remains elevated for at least three days 


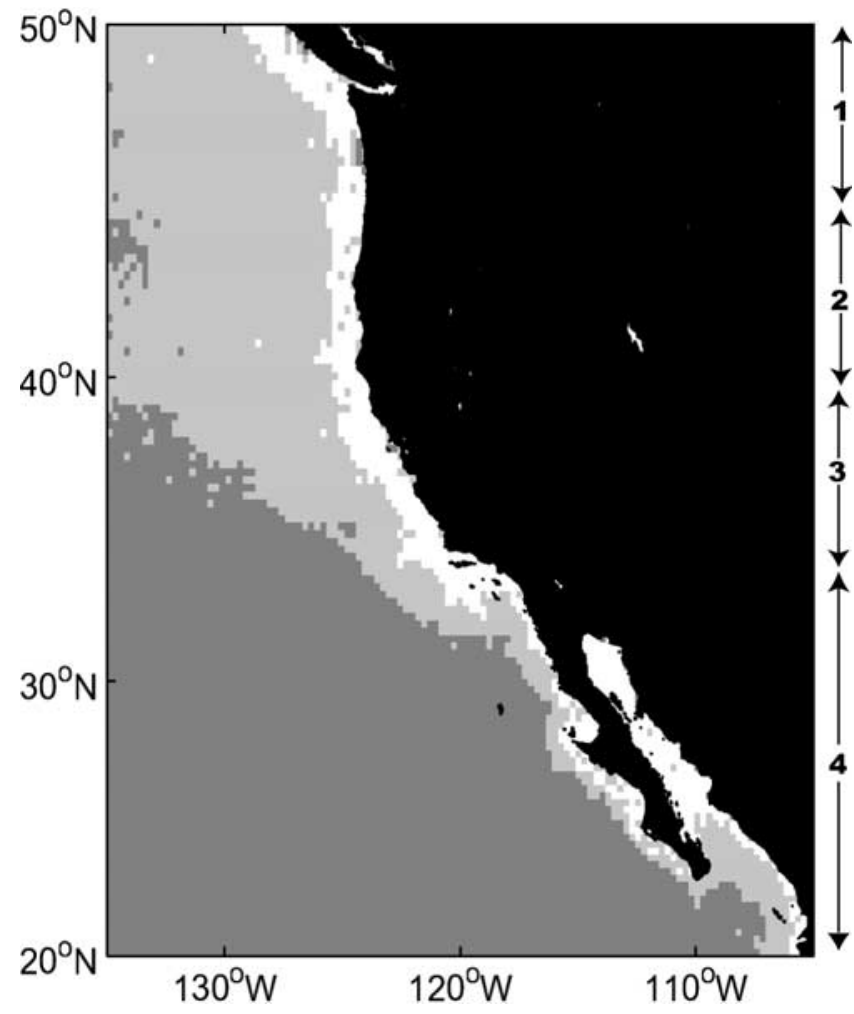

Figure 2. Spatial patterns from a cluster analysis of SeaWiFS chlorophyll a concentration, showing three biogeographical regions. The oligotrophic, offshore, and upwelling zones are shaded dark grey, light grey, and white, respectively.

[Siegel et al., 2002; Henson et al., 2006a, 2006b]. As this method identifies periods of continuously elevated chl $a$, gaps in the time series due to clouds can result in erroneous estimates of bloom timing. To reduce this problem, the data were linearly interpolated in time over gaps less than 5 days in length. As the decorrelation scale of chl $a$ in the California Current region is $\sim 1$ week [Denman and Abbott, 1994] this is not an unreasonably long period over which to interpolate. After interpolation, data gaps tended to remain only at high latitudes during winter, so were likely to have minimal impact on the estimates of bloom timing. An 8-day boxcar filter was applied to the interpolated chl $a$ data to reduce noise, which can arise from inadequate cloud masking, subpixel variability or poor atmospheric corrections. To examine the extent to which patterns of timing might be biased by filtering the chl $a$ data, or interannual variability in chl $a$ concentrations, the mean start date was calculated from climatological chl $a$, and also individually for each year before being averaged. Both calculations were performed with and without the temporal box-car filtering applied. The resulting maps of the start date were qualitatively similar, both in the range of timing and the patterns observed.

\section{Results}

\subsection{Biogeographical Zones}

[11] The cluster analysis performed on the 8-year chl $a$ time series divides the CCS region into three zones (Figure 2). Two of the zones occur approximately $>200 \mathrm{~km}$ offshore, the first in the southwest of the study area, principally south of $\sim 40^{\circ} \mathrm{N}$ (dark grey in Figure 2). The second occurs offshore in the northern part of the region (light grey), but extends the entire length of the coastline forming a boundary to the third zone (white), which consists of a narrow coastal band. The inshore area delineated by the cluster analysis stretches along the entire coastline, extending between $\sim 25 \mathrm{~km}$ and $400 \mathrm{~km}$ offshore. We consider this region to represent the spatial extent of the phytoplankton response to upwelling.

[12] The 8-year mean seasonal cycle and associated interannual variability, represented by the standard deviation, of chl $a$ in each zone is presented in Figure 3. In the southern offshore area conditions are typical of subtropical, oligotrophic regions. Chl $a$ concentrations have almost no seasonal cycle (chl $a$ remains at $\sim 0.2 \mathrm{mg} \mathrm{m}^{-3}$ all year) and very little interannual variability. This oligotrophic region is excluded from further analysis as it exhibits little seasonality and no pronounced spring bloom. The northern offshore zone displays increased seasonality with winter concentrations $\sim 0.4 \mathrm{mg} \mathrm{m}^{-3}$, rising to $\sim 0.6 \mathrm{mg} \mathrm{m}^{-3}$ from late April until late October. The inshore region has a distinct seasonal cycle, with chl $a$ rising from winter concentrations of $\sim 0.8 \mathrm{mg} \mathrm{m}^{-3}$ to a peak of $\sim 1.8 \mathrm{mg} \mathrm{m}^{-3}$ in April dropping slowly back to winter levels by mid-October. Interannual variability is greatest at the peak of the bloom in April/May (days of year 100-150).

\subsection{Timing of Seasonal Chlorophyll Increase}

[13] A map of the mean timing of the seasonal increase in chl $a$ (estimated from the climatological mean chl $a$ time series at each pixel) is plotted in Figure 4. Offshore north of $46^{\circ} \mathrm{N}$, in the Southern California Bight and the Gulf of California the seasonal increase in chl $a$ occurs in February (days 30-40). In the nearshore region, the timing of the seasonal increase in chl $a$ ranges from mid March (day 70) to late April (day 110). To the west of Baja California, increased chl $a$ begins in early to mid March (days 60-80). Between Point Conception $\left(34^{\circ} \mathrm{N}\right)$ and $\sim 46^{\circ} \mathrm{N}$ a strong offshore gradient in bloom timing occurs, delineating the boundary between the offshore region and the inshore zone where upwelling processes are likely to dominate. Start dates range from mid-March to early April (days 70-100) between $32^{\circ} \mathrm{N}$ and $37^{\circ} \mathrm{N}$, and a few days later (in late April, day 110) farther north. North of $\sim 47^{\circ} \mathrm{N}$ the offshore gradient is replaced by a latitudinal gradient. Bloom timing from $46^{\circ} \mathrm{N}$ to the edge of the study region progresses northward, ranging from mid-March to late April (days $60-110)$. This marks the transition from offshore nearoligotrophic conditions south of $45^{\circ} \mathrm{N}$, toward a more subpolar regime in the far north of the study region.

[14] Along the coast, at $\sim 44^{\circ} \mathrm{N}-46^{\circ} \mathrm{N}, 43^{\circ} \mathrm{N}$ and $38^{\circ} \mathrm{N}-$ $39^{\circ} \mathrm{N}$, patches of later start dates (days 90-110) are interspersed with areas where the bloom begins at $\sim$ days $70-90$. Figure 4 represents an 8-year mean, indicating that the features of the chl a signal which create the patchiness must be recurrent to be detected. Strong mesoscale variability, created by the interaction of the equatorward flowing coastal jet and the topography of Oregon/California coastline, is characteristic of the CCS [e.g., Strub and James, 2000; Soto-Mardones et al., 2004; Barth et al., 2005]. Many recurrent meanders and eddies form, for 

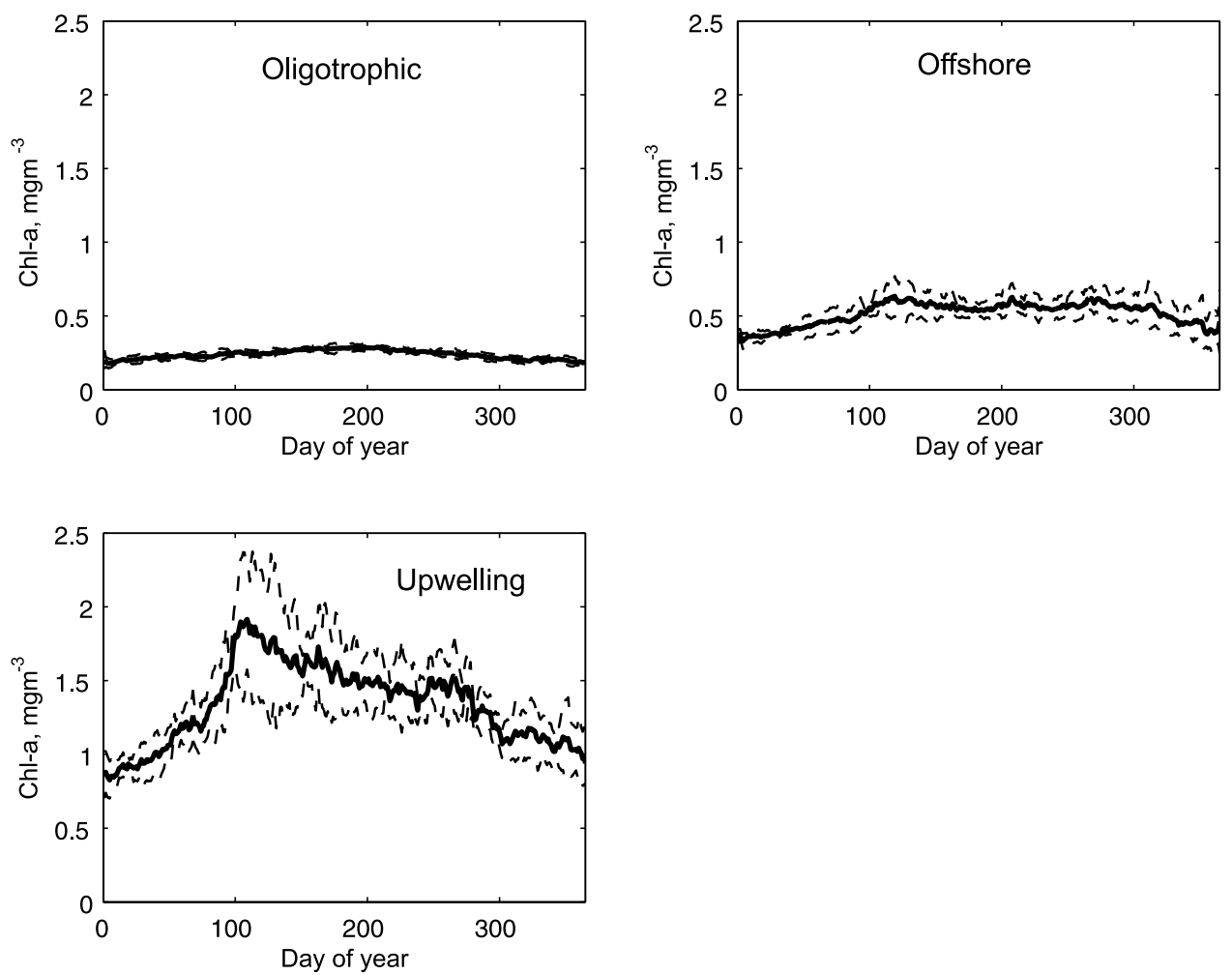

Figure 3. Eight-year (1998-2005) mean seasonal SeaWiFS chlorophyll $a$ concentration (mg m ${ }^{-3}$; solid line) for the oligotrophic, offshore and upwelling regions, as defined in Figure 2. Standard deviation within each zone, representing the interannual variability, is marked with dashed lines. Daily chl $a$ was first averaged spatially within each zone, then the 8-year mean was formed.

example, near the outflow of the Juan de Fuca strait, and in the lee of Cape Blanco, Cape Mendocino and Point Arena [Ikeda and Emery, 1984; Haidvogel et al., 1991; Barth et al., 2000; Marchesiello et al., 2003; MacFadyen et al., 2005]. The topographically tied mesoscale variability appears to create spatial heterogeneity in the bloom timing.

[15] There are two coastal regions in which the seasonal increase in chl $a$ occurs particularly early in comparison to the surrounding regions. In the Southern California Bight chl $a$ appears to start increasing in mid-February ( $\sim$ day 45 , 30 days earlier than neighboring regions). In the Bight the seasonal chl $a$ cycle is weak and a well-defined vernal peak does not occur [Thomas et al., 2001; Legaard and Thomas, 2006]. In this respect it is similar to the offshore region, which also displays early seasonal increases in chl $a$. In the case of weak seasonal variability our algorithm to estimate the bloom timing simply detects the first small rise above the annual median. An example of this difficulty is illustrated in the next section. Another region with a locally distinct and unexpectedly early start occurs along the Washington-Oregon coast at $\sim 45^{\circ} \mathrm{N}-46^{\circ} \mathrm{N}$ ( $\sim$ day 60 , rather than $\sim$ day 90). There is particularly strong variance in $\mathrm{chl} a$ in this region, which is heavily influenced by the Columbia River plume [Hickey et al., 2005; Thomas and Weatherbee, 2006] and its transport of nutrients, suspended sediment and organic matter into the coastal region. The presence of suspended particulate matter (SPM) can adversely affect the accuracy of SeaWiFS chl $a$ estimates and may bias the calculation of the timing. The additional nutrient input may

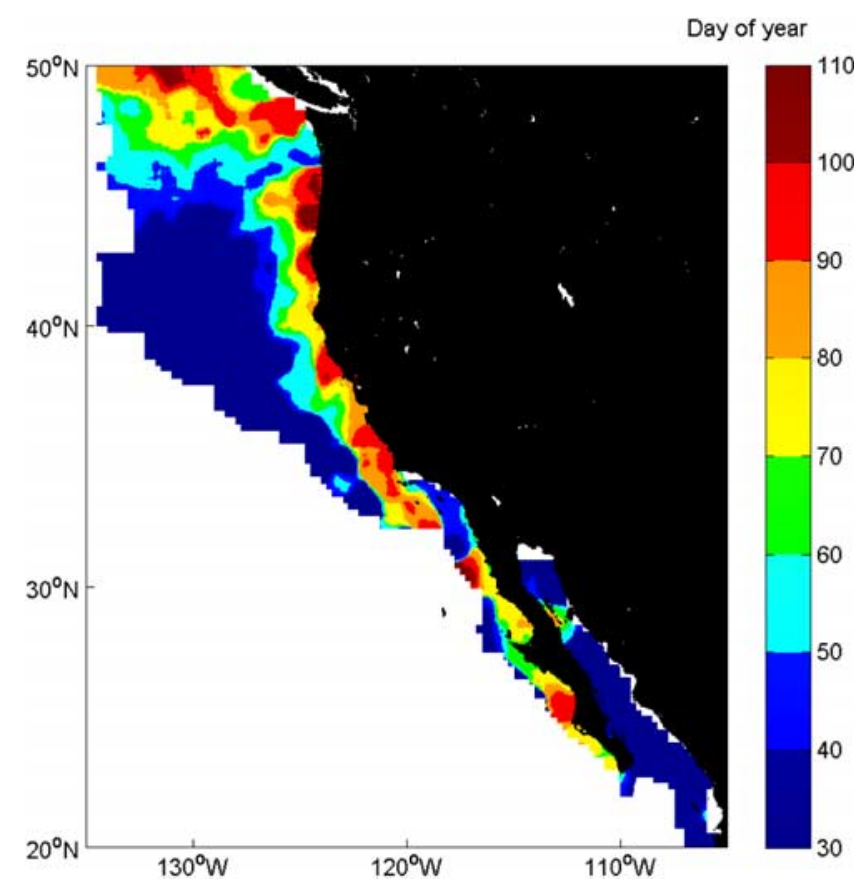

Figure 4. Spatial pattern over the California Current of the day of year on which the spring bloom starts (estimated from an 8-year mean time series of chl a). White areas denote the offshore oligotrophic zone excluded from this analysis. The data were smoothed with a $10 \times 10$ pixel $(40 \times 40 \mathrm{~km})$ median filter prior to plotting. 
also alter the timing of the seasonal increase and/or concentration of chl $a$. Alternatively, the chl $a$ concentration and timing may be influenced by the input of freshwater from the Columbia River resulting in density-driven stratification and a shallow surface layer. Time series of Columbia River discharge (http://www.cbr.washington.edu/dart/river.html) and chl $a$ data show a degree of correspondence (data not shown), suggesting a density/nutrient response may be occurring. However, Thomas and Weatherbee [2006] also reported correlation between discharge and SeaWiFS waterleaving radiance at a wavelength of $555 \mathrm{~nm}$, implying that SPM may also play a role. Unfortunately, separating the influence of the two effects is not possible with the current data set.

\subsection{Interannual Variability in Chlorophyll Timing}

[16] Interannual variability in bloom timing is shown as a function of latitude using time series of daily chl $a$ data averaged over four regions (Figure 5). The four regions encompass the $100 \mathrm{~km}$ closest to shore, averaged over $45^{\circ} \mathrm{N}-50^{\circ} \mathrm{N}$ (Region 1 ), $40^{\circ} \mathrm{N}-45^{\circ} \mathrm{N}$ (Region 2 ), $35^{\circ} \mathrm{N}-$ $40^{\circ} \mathrm{N}$ (Region 3 ) and $20^{\circ} \mathrm{N}-35^{\circ} \mathrm{N}$ (Region 4, note that the Gulf of California was excluded from the calculations). The northern part of the CCS is split into three regions (Regions 1-3), as the seasonal cycle of chl $a$ and windforcing is expected to vary more strongly with latitude than in the southern area (Region 4). The start date of the seasonal increase in $\operatorname{chl} a$, as estimated by the algorithm described in the previous section, is marked (values also in Table 1). As a measure of how representative the mean is of conditions in each region, the time series of standard deviation of chl $a$ within each zone is also plotted in Figure 5. The time series of standard deviation show that, in the majority of years and locations, variance remains low until the first large chl $a$ increase at the start of the bloom. This indicates that the regional means are not obscuring any large or widespread chl $a$ increases prior to the principal bloom, and that the estimated start date reasonably represents the first substantial region-wide increase in chl $a$.

[17] At the highest latitudes (Region 1, Washington and northern Oregon) increased chl $a$ concentrations occur between $\sim$ April and October, often with two distinct peaks, one in spring and another in late summer (e.g., in 1999 and 2002). Maximum annual chl $a$ varies from a low of $1.2 \mathrm{mg}$ $\mathrm{m}^{-3}$ in 1998 to a maximum of $2.2 \mathrm{mg} \mathrm{m}^{-3}$ in 1999 . The start of the spring increase is generally well defined, occurring between late February in 2001 and 2003 and late March in 1999. The bloom in 2005 appears to start earliest of all (early February). The unusual circumstances of 2005 will be returned to in section 4. In 2002 and 2004 our method selects the second (rather than the first) peak in chl $a$ as the start date of the bloom. Recall that the algorithm searches for the first date on which chl $a$ rises 5\% above the annual median, and stays elevated for at least 3 days. In years when the annual median value is high, or the chl $a$ concentration is temporally very variable, the algorithm may miss the first chl $a$ increase. In both 2002 and 2004 this results in an estimated start date which is $\sim 20$ days later than that which we may have subjectively selected.

[18] In Region 2 (southern Oregon and northern California) the seasonal increase in chl $a$ in many years is more gradual than in Region 1. A small spring peak is often followed by a larger midsummer bloom, as in 1998 and 2000. Maximum chl $a$ concentration varies between $0.9 \mathrm{mg} \mathrm{m}^{-3}$ in 1998 and $2.1 \mathrm{mg} \mathrm{m}^{-3}$ in 2005. Start dates show the largest interannual variability of all the regions, ranging from late February in 1998 and 2004 to late May in 2003. In 1999, the chl $a$ never reaches a distinct peak, varying between just 0.35 and $0.9 \mathrm{mg} \mathrm{m}^{-3}$. The corresponding standard deviation shows low variance throughout the year, suggesting that the weakened chl $a$ in 1999 is genuine and not an artifact of the spatial averaging. In 2005 the start date algorithm selects early February, but the large increase in chl $a$ does not occur until late June (see section 4).

[19] In Region 3 (central California) a spring peak in chl $a$ occurs in some years (e.g., 2000, 2004 and 2005), although not as sharply defined as in Region 1 . In other years, chl $a$ has a very weak seasonal signal, merely oscillating around the mean, as in 1998 or 2003. Maximum chl $a$ ranges from $0.9 \mathrm{mg} \mathrm{m}^{-3}$ in 1998 to $1.8 \mathrm{mg} \mathrm{m}^{-3}$ in 2005 . Start dates vary between late February in 1998 and 1999 and early April in 2001 and 2005. In years without a clear seasonal cycle, the start date algorithm sometimes has difficulties in selecting the beginning of the seasonal increase in chl $a$ (this is particularly apparent in 1998 and 2003). The time series show that selecting the start of the seasonal increase subjectively would be equally problematic in these cases.

[20] At lowest latitudes (Region 4, Southern and Baja California) a strong seasonal cycle is present with increased chl $a$ occurring between $\sim$ February and July. The earliest start date occurs in late January in 2001 and the latest in late March in 2005. Maximum chl a concentration varies between $1.1 \mathrm{mg} \mathrm{m}^{-3}$ in 1998 and $2.1 \mathrm{mg} \mathrm{m}^{-3}$ in 2000 . In certain years (e.g., 2001 and 2005) the start of the seasonal increase in chl $a$ is well-defined, but in others the increase is more gradual (e.g., 1999 and 2004). In 2002 and 2004 the algorithm selects the second increase in chl $a$, rather than the first, as the start date. This is due either to a high annual median value, or temporally variable chl $a$ concentration, which results in the algorithm missing the first chl $a$ increase.

\subsection{Timing of Physical Processes in Spring}

[21] Interannual variability in the timing of the seasonal increase in chlorophyll is likely to be driven by physical forcing, of which the timing of the transition to upwellingfavorable winds is expected to be a key factor. In the southern portion of the study region, winds are predominantly southward year-round. North of $\sim 35^{\circ} \mathrm{N}$, a switch from northward winds in winter to southward winds in spring heralds the beginning of the upwelling season. With increasing latitude, increased storm-related variability may result in episodic upwelling events in early spring, prior to the establishment of sustained seasonal upwelling. In the northernmost regions of the CCS, although long-term means show summer upwelling, wind direction is highly variable and periods of upwelling-favorable winds can occur intermittently throughout the year.

[22] We quantify the timing of the first period of sustained upwelling-favorable winds as the day on which satellite-derived alongshore wind stress has been upwelling-favorable for at least 10 of the last 14 days. This criterion allows for temporary reversals of the prevailing winds, which may occur early in the season prior to the 
Region 1
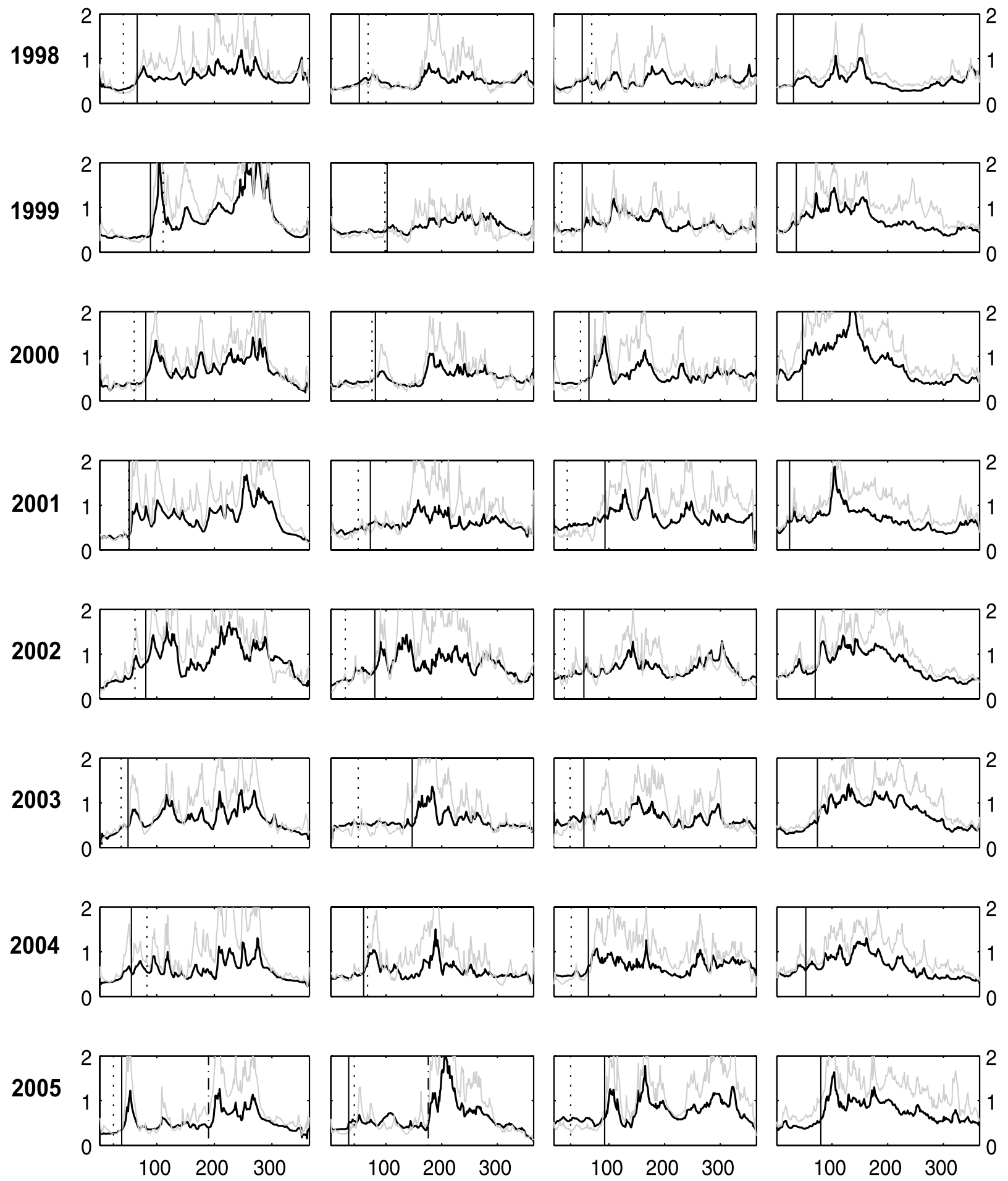

Day of year

Figure 5. Time series of daily SeaWiFS chl $a$ data for 1998-2005 averaged over four regions (solid black line): Region $1,45^{\circ} \mathrm{N}-50^{\circ} \mathrm{N}$; Region $2,40^{\circ} \mathrm{N}-45^{\circ} \mathrm{N}$; Region $3,35^{\circ} \mathrm{N}-40^{\circ} \mathrm{N}$; and Region 4 , $20^{\circ} \mathrm{N}-35^{\circ} \mathrm{N}$. Standard deviation of chl $a$ within each region marked with solid grey line. Estimated start date of the seasonal increase in chl $a$ is marked by a vertical solid line. Vertical dashed line marks the start of the first episode of upwelling-favorable winds (except in Region 4). In 2005 the dash-dotted line in Regions 1 and 2 marks the start date of the period of sustained chl $a$ increase. 
Table 1. Estimated Start Date of the Seasonal Increase in chl $a$ in Four Regions ${ }^{\mathrm{a}}$

\begin{tabular}{|c|c|c|c|c|c|}
\hline & $\begin{array}{c}\text { Region } 1 \\
45^{\circ} \mathrm{N}-50^{\circ} \mathrm{N} \\
\end{array}$ & $\begin{array}{c}\text { Region } 2 \\
40^{\circ} \mathrm{N}-45^{\circ} \mathrm{N} \\
\end{array}$ & $\begin{array}{c}\text { Region } 3 \\
35^{\circ} \mathrm{N}-40^{\circ} \mathrm{N}\end{array}$ & $\begin{array}{c}\text { Region } 4 \\
20^{\circ} \mathrm{N}-35^{\circ} \mathrm{N} \\
\end{array}$ & $\begin{array}{c}\text { Annual } \\
\text { Mean }\end{array}$ \\
\hline & 66 & 52 & 52 & 31 & 50 \\
\hline \multirow{3}{*}{1998} & 42 & 68 & 69 & & 60 \\
\hline & 24 & -16 & -17 & & \\
\hline & 89 & 102 & 52 & 36 & 70 \\
\hline \multirow[t]{3}{*}{1999} & 111 & 100 & 15 & & 75 \\
\hline & -22 & 2 & 37 & & \\
\hline & 81 & 81 & 64 & 47 & 68 \\
\hline \multirow[t]{3}{*}{2000} & 61 & 75 & 49 & & 62 \\
\hline & 20 & 6 & 15 & & \\
\hline & 52 & 72 & 93 & 24 & 60 \\
\hline \multirow[t]{3}{*}{2001} & 51 & 50 & 25 & & 42 \\
\hline & 1 & 22 & 68 & & \\
\hline & 81 & 80 & 55 & 70 & 72 \\
\hline \multirow[t]{3}{*}{2002} & 62 & 27 & 20 & & 36 \\
\hline & 19 & 53 & 35 & & \\
\hline & 50 & 147 & 55 & 71 & 82 \\
\hline \multirow[t]{3}{*}{2003} & 38 & 50 & 30 & & 39 \\
\hline & 12 & 97 & 25 & & \\
\hline & 56 & 60 & 63 & 53 & 58 \\
\hline \multirow[t]{3}{*}{2004} & 83 & 67 & 32 & & 61 \\
\hline & -27 & -7 & 31 & & \\
\hline & 39 (190) & 33 (176) & 92 & 80 & $61(135)$ \\
\hline \multirow[t]{3}{*}{2005} & 25 & 43 & 31 & & 33 \\
\hline & 14 & -10 & 61 & & \\
\hline & 64 & 78 & 66 & 52 & \\
\hline \multirow{2}{*}{ Regional mean } & 59 & 60 & 34 & & \\
\hline & 5 & $7^{b}$ & 32 & & \\
\hline
\end{tabular}

\footnotetext{
${ }^{a}$ Estimated start date is given as day of year. Values in brackets in 2005 in Regions 1 and 2 and for the 2005 annual mean indicate the start of the sustained increase in chl $a$ (see Figure 5 and section 4 for more details). Italic numbers are day of year of first episode of sustained upwelling-favorable winds (except in Region 4; see text). Bold numbers are the difference (in days) between the two events. Positive (negative) numbers indicate that wind leads (lags) chl $a$. Final column and final row show annual and regional means respectively for each parameter.

${ }^{\mathrm{b}}$ Regional mean difference for Region 2 excludes 2003.
}

establishment of persistent upwelling conditions. South of $\sim 35^{\circ} \mathrm{N}$ (i.e., in Region 4) the prevailing wind direction is southward throughout the year and the concept of the timing of a switch to upwelling-favorable winds is thus invalid. The factors influencing the timing of the seasonal chl $a$ increase in Region 4 are examined in section 4.

[23] The dates of the first episode of persistently upwelling-favorable winds are shown in Figure 5 and in Table 1 for comparison to the timing of the chl $a$ increase (except in Region 4). On average the mean date is similar in Regions 1 and 2 ( early March) and one month later than in Region 3 ( early February). Averaged over all regions, the earliest episodes of upwelling-favorable winds occur in 2005 ( early February) and latest in 1999 ( mid-March). Region 1 follows the mean pattern, with the earliest start date in 2005 (late January) and latest in 1999 (late April). The earliest start date in Region 2 occurs in 2002 (late January), and latest in 1999 (mid-April). In Region 3 the earliest start date is again in 2002 (mid-January) and latest in 1998 (early March).

[24] In Region 1 the first episode of upwelling-favorable winds generally leads the start of the seasonal increase in chl $a$, except in 1999 and 2004 when chl $a$ increases $\sim 20$ days prior to the winds. The start of increased chl $a$ in Region 2 usually occurs within a few days of the onset of upwelling winds, except in 2002 and 2003, where the lag is 53 and 97 days respectively. In 2002 the algorithm selects the second peak in chl $a$, rather than the first, which does coincide with the timing of upwelling-favorable winds. In
2003, despite upwelling-favorable winds in mid-February, chl $a$ concentrations remain low until the end of May. In Region 3 the difference between the timing of upwellingfavorable winds and increased chl $a$ is longer than in the other two regions. The first episode of upwelling-favorable winds usually occurs in late January or early February, and increased chl $a$ in early March. In Region 3, and Region 2 in 2003 , long lags may be related to factors not captured by our algorithm, such as intensity of the upwelling winds, or episodic periods of downwelling winds which interrupt bloom development. Additionally, other environmental factors, such as poor light conditions or an unusually deep winter mixed layer, may have delayed the start of increased chl $a$.

[25] The difference in timing of the seasonal increase in chl $a$ and the first episode of upwelling-favorable winds is shown in Table 1. In Region 1 the two events generally coincide (mean difference is $\sim 5$ days). In Region 2 the two events also often occur within a few days of each other, with the exception of 2003. Excluding 2003, the mean difference is $\sim 7$ days. In Region 3 the difference is larger, with upwelling-favorable winds occurring, on average, $\sim 32$ days prior to the chl $a$ increase.

\section{Discussion}

[26] The overall average lag between the first episode of upwelling-favorable winds and the seasonal increase in coastal chl $a$ is $\sim 15$ days. Some delay between the onset of southward winds and a response in phytoplankton is to 
be expected. First, the wind stress may be upwellingfavorable, but the geostrophic adjustment of the ocean to the forcing will not occur immediately. Plots of adjusted sea level and alongshore wind stress for 33 to $48^{\circ} \mathrm{N}$ [Strub et al., 1987a] suggest that a drop in sea level occurs between 2 and 5 days after the onset of persistently southward winds. Additionally, for phytoplankton growth to occur a southward wind event must be sufficiently intense or long-lasting to introduce subsurface, nutrient-rich water into the euphotic zone. Observations suggest that the cold SST signature of upwelled water lags the sea level transition by 3 to 5 days [Strub et al., 1987a]. Finally, chl $a$, a proxy for biomass, will not increase instantaneously when upwelling occurs. An initial physiological response (e.g., light adaptation, increased nutrient uptake rate and growth) must occur before biomass increases. This potential lag is difficult to quantify, as it depends on seed concentrations, species composition, physiological state, grazing by zooplankton and environmental conditions. As a minimum, average phytoplankton doubling times are $\sim 1$ day [Lalli and Parsons, 1997]. At a Monterey Bay mooring, a lag of $\sim 7$ days between upwelling-favorable winds and increased fluorescence was observed [Service et al., 1998]. In the vicinity of Point Conception phytoplankton take $\sim 9$ days to achieve maximal nutrient uptake rates after being upwelled [Dugdale and Wilkerson, 1989], and 5 to 6 days in the upwelling center off Peru [MacIsaac et al., 1985]. Modeling and observational studies [e.g., Sharples, 1999; Morin et al., 1985] in tidal fronts suggest a lag of up to 3 to 4 days between the introduction of new nitrate and chlorophyll increases. The resulting increase in biomass must also be sufficiently large-scale and long-lasting, and be expressed at the surface, for SeaWiFS to detect it. On the basis of these multiple factors, uncertainty in the data time series and error in estimating the start date, a mean lag of $\sim 15$ days between the first episode of upwelling-favorable winds and an increase in chl $a$ is not unreasonable. The similarity in timing that we observe, particularly in Regions 1 and 2, suggests that the timing of the transition from northward to upwelling-favorable winds plays a substantial role in determining the timing of the spring increase in chlorophyll in the northern CCS.

[27] Does the timing of the $\operatorname{chl} a$ increase influence the magnitude of the bloom? The year with the lowest chl $a$ concentrations in every region is 1998. However, a small, though suppressed, seasonal cycle is still present and the start of the increase in chl $a$ is earlier than average. In 1997/ 1998 a strong El Niño occurred and in the CCS weak upwelling-favorable winds resulted in warm SST and low biological productivity [Chavez et al., 2002, and references therein]. It seems that the El Niño conditions limited the magnitude of the bloom through reduced upwelling, but did not result in a delay to the seasonal chl $a$ cycle. Unusual conditions also occurred in 2002 associated with an intrusion of subarctic water into the northern CCS [Huyer, 2003, and references therein]. The estimated start of the bloom is very similar to the average, and although the maximum chl $a$ concentration in 2002 in Regions 1 and 2 was high, it was not the highest observed. (In Regions 3 and 4, chl $a$ is at average concentrations in 2002). The maximum concentration is not, however, a particularly good measure of the overall magnitude of a bloom. A better index may be the duration of sustained increased chlorophyll, or the total integrated bloom-period chl a concentration (dubbed the intensity index by Fleming and Kaitala [2006]). An estimate of the latter quantity was calculated by summing all daily chl $a$ values which were greater than $5 \%$ above the annual median (i.e., the chlorophyll concentration at the start of the bloom). Although this does not represent any physical quantity, it is useful as a comparative tool. In 2002 the intensity index was greater than in any other year in Regions 1 and $2\left(181 \mathrm{mg} \mathrm{m}^{-3}\right.$ in 2002 , compared to a mean of $136 \mathrm{mg} \mathrm{m}^{-3}$ in other years), suggesting that the slightly later than average bloom start had no deleterious effect on chl $a$ magnitude. Overall the timing of the seasonal increase in $\operatorname{chl} a$ bears no relation either to maximum chl $a$ concentration or intensity of the bloom. In this region the physical conditions which regulate upwelling, and the supply of nutrients, throughout spring and summer are likely to be most influential in determining the magnitude of the bloom.

\subsection{Southern and Baja California: Region 4}

[28] Wind stress in the southern CCS is upwelling-favorable year-round, yet a distinct seasonal cycle in chl $a$ is evident in Figure 5. The start of increased chl $a$ occurs in early February to mid-March and concentrations remain elevated into early autumn. The coastal upwelling index, calculated as the offshore component of the Ekman transport driven by geostrophic wind stress [Bakun, 1973], is always positive in this region (i.e., upwelling, rather than downwelling, conditions). However, there is a seasonal cycle in the intensity of upwelling, which is minimum in winter, increases sharply in February/March and reaches a maximum in May [e.g., Espinosa-Carreon et al., 2004]. The daily upwelling index from $1998-2005$ at $27^{\circ} \mathrm{N}$ (center of Region 4) is plotted in Figure 6 along with the Region 4 chl $a$ time series. With the exception of 1998, there is a strong correspondence between the timing of the seasonal increase in chl $a$ and in upwelling intensity.

[29] At this southerly latitude solar heating is strong and a relatively shallow surface mixed layer is present year-round [e.g., Husby and Nelson, 1982]. In winter wind stress and upwelling may be too weak to overcome the stratification and limited new nutrients are introduced into the euphotic zone. In February/March, as southward wind stress increases, upwelling strength rises sharply, sufficient to overcome surface heating. The rapid increase in chl $a$ which then occurs suggests that either, (1) the surface waters are nutrient limited and the mixing results in injection of new nutrients into the euphotic zone leading to new growth, or (2) phytoplankton from the subsurface chlorophyll maximum which is present in this region [Cullen and Eppley, 1981; Hayward et al., 1995; Millan-Nunez et al., 1997] are mixed into surface waters, where they become detectable by the SeaWiFS instrument.

[30] This result is consistent with the close correspondence between the timing of seasonal increases in chl $a$ and onset of upwelling winds observed farther north in Regions 1-3. In Region 4 however, the seasonal cycle in upwelling intensity, rather than seasonal reversals in wind direction, influences the timing of increased chl $a$ concentrations. 


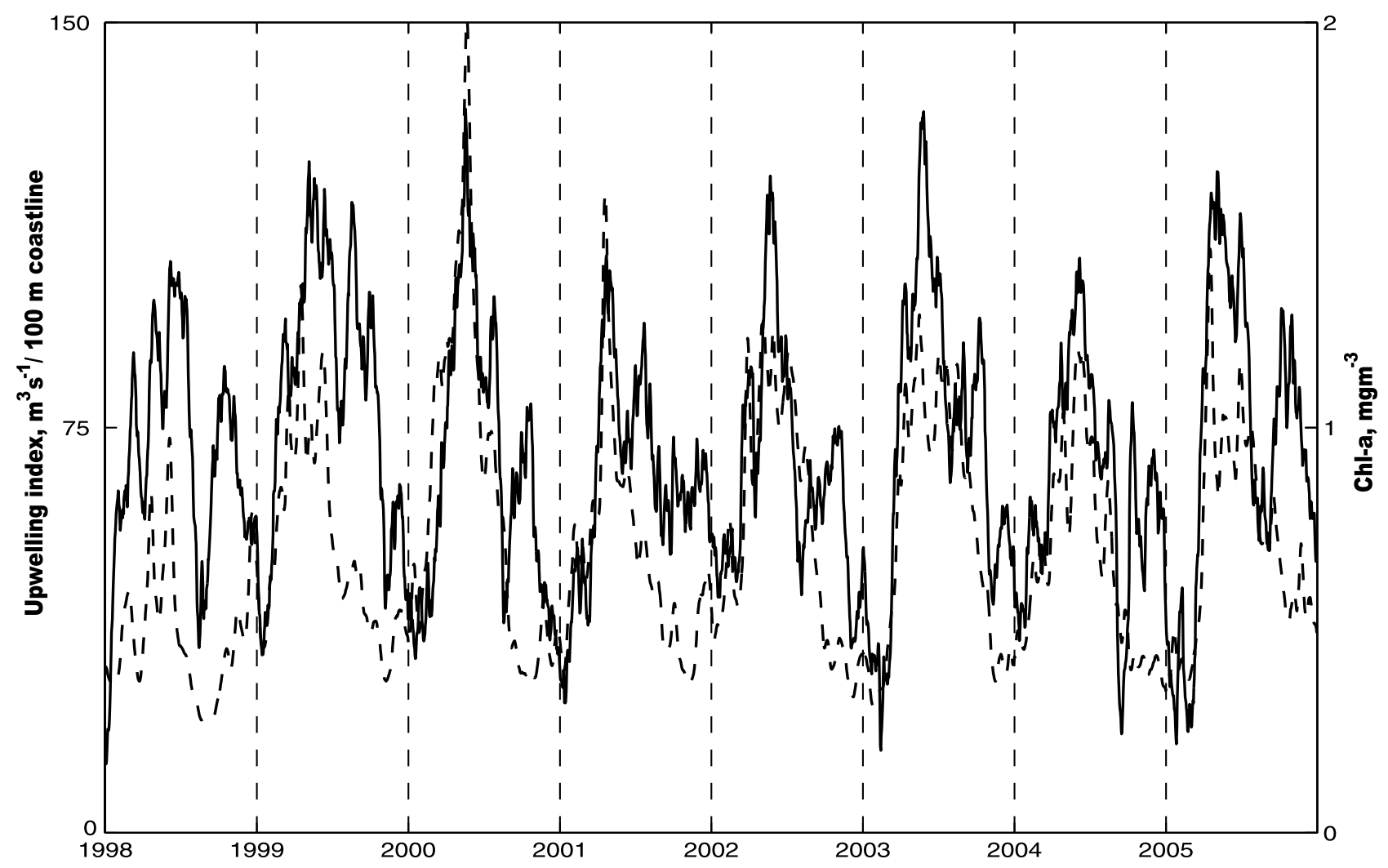

Figure 6. Time series of daily upwelling index at $27^{\circ} \mathrm{N}$ (solid line) and Region 4 daily chl $a$ concentration (dashed line). Upwelling index data were downloaded from http://www.pfeg.noaa.gov/ products/las.html.

\subsection{North Oregon/Washington Coast: Region 1}

[31] The possibility of light limitation of phytoplankton growth in winter/early spring in the northern CCS has been raised in previous studies. Using a model tuned to $\sim 40^{\circ} \mathrm{N}$, Thomas and Strub [1989] calculated that, over a 5-year period, the depth averaged irradiance in the CCS did not exceed the theoretical minimum for phytoplankton growth [Riley, 1957] until mid-March, making a phytoplankton bloom unlikely to occur before this time. Bottle experiments [Wetz et al., 2004] in January at $\sim 45^{\circ} \mathrm{N}$ on the Oregon shelf demonstrated that adding nutrients to phytoplankton samples did not encourage growth, but increased irradiance resulted in large increases in chl $a$. Both Corwith and Wheeler [2002] and Small and Menzies [1981] also concluded that as chlorophyll concentrations remain low in winter, but nutrients are plentiful, phytoplankton are most likely limited by light in the Oregon coastal region. Farther south, in the region of Crescent City, California $\left(\sim 42^{\circ} \mathrm{N}\right)$, evidence of light limited phytoplankton photosynthesis due to deep mixed layers has also been found [Huyer et al., 2005].

[32] The timing of the onset of upwelling-favorable winds clearly plays an important role in the timing of the phytoplankton spring bloom in Region 1 (Figure 5). However, the time series of upwelling-favorable winds and chl $a$ used to create Figure 5 were averaged over $5^{\circ}$ of latitude. Examination of individual time series in the coastal region north of $\sim 46^{\circ} \mathrm{N}$ often found lags between the first episode of upwelling-favorable winds and increased chl $a$ of 50 days or greater. This lag becomes more pronounced with increasing latitude, suggesting light limitation of early seasonal phytoplankton growth.

[33] In the classic Sverdrup definition of the conditions necessary for bloom initiation, the depth-averaged irradiance in the upper mixed layer must be greater than the compensation irradiance, the equivalent depth at which production is greater than respiration [Sverdrup, 1953]. An empirical value for the compensation irradiance was defined by Riley [1957] as $21 \mathrm{~W} \mathrm{~m}^{-2}$, and has since been used extensively (examples from the CCS are given by Thomas and Strub [1989] and Huyer et al. [2005]). The depth-averaged irradiance, $\bar{I}$, is defined as

$$
\bar{I}=\frac{I_{0}\left(1-e^{-k z}\right)}{k z},
$$

where $I_{0}$ is the incident irradiance, $k$ is the attenuation coefficient and $z$ is the depth of the mixed layer. Thus the depth-averaged irradiance can become sufficient for bloom initiation through two mechanisms, either shallowing of the mixed layer and/or increases in the incident irradiance.

[34] A time series of the depth-averaged irradiance was calculated to investigate whether insufficient light could delay the start of the bloom. The incident irradiance is taken from daily SeaWiFS PAR products and the attenuation coefficient is set at a constant $0.1 \mathrm{~m}^{-1}$ (mean SeaWiFSderived $k_{490}$ from http://reason.gsfc.nasa.gov/Giovanni/). A 1-D model (described in section 2) was used to estimate the 

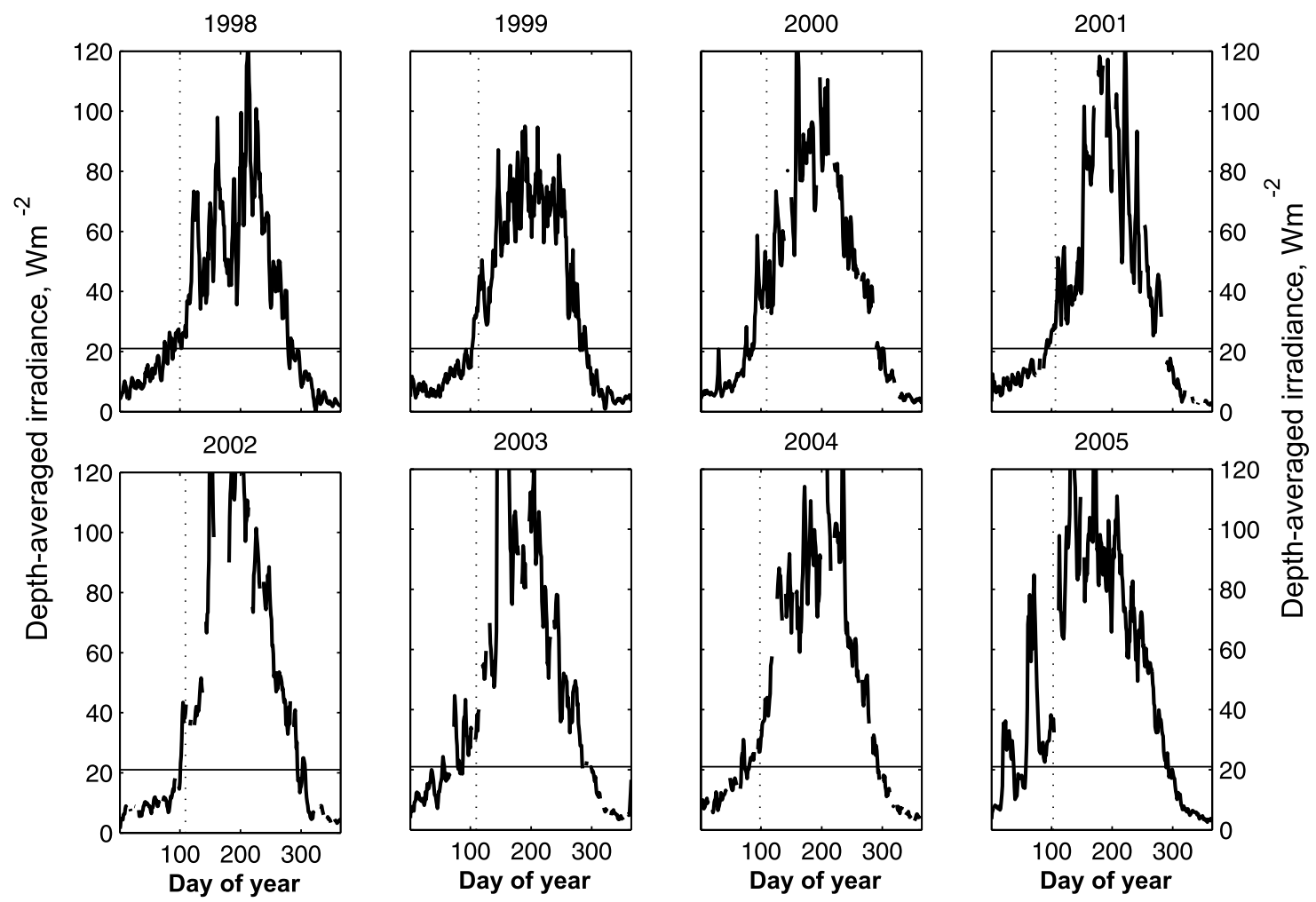

Figure 7. Annual cycle of depth-averaged irradiance $\left(\mathrm{W} \mathrm{m}^{-2}\right)$ calculated at $50^{\circ} \mathrm{N}$ using modeled mixed layer depth and SeaWiFS PAR data in equation (1). The start date of the spring bloom at $50^{\circ} \mathrm{N}$ (dashed vertical line) and Riley's [1957] theoretical minimum depth-averaged irradiance required for bloom initiation, $21 \mathrm{~W} \mathrm{~m}^{-2}$ (solid horizontal line), are marked.

seasonal cycle in mixed layer depth. The model was run at several latitudes from $20^{\circ} \mathrm{N}$ to $50^{\circ} \mathrm{N}$ for water depths greater than $500 \mathrm{~m}$ and within $\sim 250 \mathrm{~km}$ of the coast. (Exact locations were determined by available Argo float data). In Figure 7 the daily depth-averaged irradiance at $50^{\circ} \mathrm{N}$ is plotted for each study year. The theoretical minimum $\bar{I}$ of $21 \mathrm{~W} \mathrm{~m}^{-2}$ is marked, as is the start date of the spring bloom at $50^{\circ} \mathrm{N}$. It is clear that although episodes of upwellingfavorable winds may occur as early as mid February, there is inadequate light for sustained phytoplankton growth to occur. Results of model runs south of $\sim 40^{\circ} \mathrm{N}$ (not shown) confirm that depth-averaged irradiance is sufficient at these latitudes, even in winter, for phytoplankton growth, owing to high incident light and relatively shallow mixed layers. In the far north of the CCS (north of $\sim 46^{\circ} \mathrm{N}$ ), upwelling-favorable winds alone are not sufficient to prompt the start of the seasonal increase in chl $a$. Until approximately mid-March light limitation prevents substantial phytoplankton growth.

\subsection{An Unusual Year: 2005}

[35] An early but short-lived increase in chl $a$ occurred in February 2005 (Figure 5). The peak recedes again quickly within $\sim 3$ weeks to winter concentrations. Not until early July does a large and sustained increase in biomass occur (marked in Figure 5). This date was estimated by applying the start date algorithm to data from March onward only. This anomalous seasonal pattern in 2005 was most pronounced in Region $1\left(45^{\circ} \mathrm{N}-50^{\circ} \mathrm{N}\right)$, but also evident in Regions 2 and $3\left(40^{\circ} \mathrm{N}-45^{\circ} \mathrm{N}\right.$ and $35^{\circ} \mathrm{N}-40^{\circ} \mathrm{N}$, respectively). The timing of the February burst of increased chl $a$ occurs in conjunction with the first episode of upwelling-favorable winds (Figure 5). The 8 years of modeled light availability shows 2005 to be the only year in which the depth-averaged irradiance rises above the critical value as early as February (Figure 7). This early short-lived increase in chl $a$ was therefore a response to a brief period when conditions where conducive to phytoplankton growth. Kosro et al. [2006] note that anomalously strong upwelling winds occurred in February 2005, followed by a period of strong downwelling which lasted until late May. This return to predominantly downwelling winds likely caused the rapid decrease in chl $a$ back to winter concentrations. Kosro et al. [2006] suggest that the major seasonal biological response (based on the appearance of cold upwelled water at the surface) began on 13 July (day 194), remarkably close to our estimate (Table 1).

[36] Massive mortality of planktivorous seabirds occurred in the northern CCS in 2005 [Sydeman et al., 2006]. Unusually warm temperatures and delayed upwelling were also reported [Pierce et al., 2006; Schwing et al., 2006]. From March-June, north of $40^{\circ} \mathrm{N}$, but strongest from $46^{\circ} \mathrm{N}-50^{\circ} \mathrm{N}$, both chlorophyll and primary production were anomalously weak [Thomas and Brickley, 2006; Kudela et $a l ., 2006]$. The daily satellite chl $a$ data presented here offers further insight into the unusual conditions of 2005 and the possible ecological interactions. We hypothesize that the "false start" to the seasonal phytoplankton bloom in February 2005 lasted sufficiently long for higher trophic levels to respond. Sydeman et al. [2006] note that the cold, 
upwelling conditions in February could have "miscued" planktivorous auklets to initiate breeding. The meteorological conditions in March, which reduced chl $a$ concentrations back to winter levels, deprived higher trophic levels of a food source. Phytoplankton biomass recovered in July, reaching some of the highest chl $a$ concentrations in our 8-year record. However, by this time seabird mortality had already reached its peak [Sydeman et al., 2006]. We suggest that it was not a shortage of food, but rather a mismatch in the timing of its availability to higher trophic levels, that was responsible for the unprecedented failure of the 2005 seabird breeding season in the northern CCS.

\section{Summary}

[37] Use of daily satellite chlorophyll data in this study documents the interannual variability in bloom characteristics over 8 years at high spatial and temporal resolution. Inclusion of satellite-derived wind data allows direct comparisons between the timing of the first period of increased chl $a$ concentrations and of upwelling-favorable winds along the full latitudinal extent of the CCS.

[38] Our method for estimating the start date of the seasonal increase in $\operatorname{chl} a$ allows maps of bloom timing to be constructed. The algorithm works well in regions with a distinct seasonal cycle, but struggles in areas with weak seasonality, such as the Southern California Bight. The method assists in highlighting the interannual and regional variability in the timing of the spring bloom. The seasonal increase in chl $a$ generally starts earliest off southern California and latest off Oregon. On average, the earliest increases in chl $a$ occur in 1998, also the year with the lowest magnitude blooms. The seasonal increase in 2005 occurs latest and has the highest magnitude chlorophyll concentration. Excluding 2005, the latest blooms occur in 2003 with maximum chl $a$ concentrations observed in 2000 and 2001.

[39] The first sustained episode of upwelling-favorable winds generally coincides with the seasonal increase in chl $a$. In the northernmost part of the $\operatorname{CCS}\left(>\sim 46^{\circ} \mathrm{N}\right)$ however, we demonstrate that light limitation during winter is likely to play a role in the timing of the spring bloom. Episodes of upwelling-favorable winds may occur as early as February, but do not result in a phytoplankton response owing to insufficient irradiance. In the southern CCS winds are southward year-round, so the timing of the onset of upwelling-favorable winds is a moot point. Instead we find that the timing of seasonally increased chl $a$ corresponds closely to the timing of increased upwelling intensity. There is occasionally a large disparity between the timing of upwellingfavorable winds and an increase in $\operatorname{chl} a$. As noted by Kosro et al. [2006], the timing of the physical transition can be distinct from the timing of the biological response.

[40] Other indicators of the physical spring transition, aside from the switch to southward winds, have also been used, such as a drop in coastal sea level [Strub et al., 1987a], increases in cross-shelf density gradients [Huyer et al., 1978; Lynn et al., 2003], the establishment of southward surface flow [Kundu et al., 1975] or a drop in sea surface temperature [Strub et al., 1987b]. It is possible that using one of these metrics would result in a closer agreement between the timing of the phytoplankton growth season and the spring transition. We use changes in alongshore wind stress because of the availability of high temporal and spatial resolution data which coincides with the satellite chl $a$ record. We have also not taken into account in this analysis the intensity or duration of southward wind events, factors which are likely to have an impact on the development of the bloom.

[41] Unusual conditions prevailed in 2005. The bloom had an early "false start" in February, responding to a brief period of upwelling-favorable winds and good light conditions. An extended period of downwelling-favorable winds from March-June reduced the chl $a$ concentration back to winter levels, where they remained until upwellingfavorable conditions resumed in July. The phytoplankton responded quickly and a vigorous bloom continued until $\sim$ September. The mismatch in timing of food availability to higher trophic levels may have contributed to the widespread failure of planktivorous seabirds in 2005 .

[42] Acknowledgments. Joanna Waniek supplied the Matlab version of the 1-D model used and Peter Brickley performed the initial processing of the SeaWiFS L2 data, for which we are very grateful. SeaWiFS data were provided by GSFC/NASA in accord with the SeaWiFS Research Data Use Terms and Conditions Agreement. The Argo data were collected and made freely available by the International Argo Project and supplied by the Coriolis project. NCEP Reanalysis heat flux data were provided by the NOAA-CIRES Climate Diagnostics Center, Boulder, Colorado, USA. QuikScat data were produced by Remote Sensing Systems, sponsored by the NASA Ocean Vector Winds Science Team. This work was funded by NSF grants OCE-0535386 and OCE-0531289 to ACT. This is GLOBEC contribution 524 .

\section{References}

Abbott, M. R., and B. Barksdale (1991), Phytoplankton pigment patterns and wind forcing off central California, J. Geophys. Res., 96(C8), $14,649-14,667$

Bakun, A. (1973), Coastal upwelling indices, west coast of North America, 1946-71, NOAA Tech. Rep. NMFS SSRF-671, U.S. Dep. of Commer., Washington, D. C.

Bakun, A., and C. S. Nelson (1991), The seasonal cycle of wind stress curl in subtropical eastern boundary current regions, J. Phys. Oceanogr., 21(12), 1815-1834.

Barth, J. A., S. D. Pierce, and R. L. Smith (2000), A separating coastal upwelling jet at Cape Blanco, Oregon and its connection to the California Current System, Deep Sea Res., Part II, 47(5-6), 783-810.

Barth, J. A., S. D. Pierce, and T. J. Cowles (2005), Mesoscale structure and its seasonal evolution in the northern California Current System, Deep Sea Res., Part II, 52(1-2), 5-28.

Batchelder, H. P., and T. M. Powell (2002), Physical and biological conditions and processes in the northeast Pacific Ocean, Prog. Oceanogr., 53(2-4), 105-114.

Chavez, F. P., C. A. Collins, A. Huyer, and D. L. Mackas (2002), El Niño along the west coast of North America, Prog. Oceanogr., 54(1-4), 1-5.

Corwith, H. L., and P. A. Wheeler (2002), El Niño related variations in nutrient and chlorophyll distributions off Oregon, Prog. Oceanogr., 54(1-4), 361-380

Cullen, J. J., and R. W. Eppley (1981), Chlorophyll maximum layers of the Southern California Bight and possible mechanisms of their formation and maintenance, Oceanol. Acta, 4(1), 23-32.

Denman, K. L., and M. R. Abbott (1994), Timescales of pattern evolution from cross-spectrum analysis of advanced very high resolution radiometer and coastal zone color scanner imagery, J. Geophys. Res., 99(C4), 7433-7442.

Dugdale, R. C., and F. P. Wilkerson (1989), New production in the upwelling center at Point Conception, California-Temporal and spatial patterns, Deep Sea Res. Part I, 36(7), 985-1007.

Espinosa-Carreon, T. L., P. T. Strub, E. Beier, F. Ocampo-Torres, and G. Gaxiola-Castro (2004), Seasonal and interannual variability of satellite-derived chlorophyll pigment, surface height, and temperature off Baja California, J. Geophys. Res., 109, C03039, doi:10.1029/2003JC002105.

Fleming, V., and S. Kaitala (2006), Phytoplankton spring bloom intensity index for the Baltic Sea estimated for the years 1992 to 2004, Hydrobiologia, 554, 57-65. 
Haidvogel, D. B., A. Beckmann, and K. S. Hedstrom (1991), Dynamical simulations of filament formation and evolution in the coastal transition zone, J. Geophys. Res., 96(C8), 15,017-15,040.

Hayward, T. L., D. R. Cayan, P. J. S. Franks, R. J. Lynn, A. W. Mantyla, J. A. McGowan, P. E. Smith, F. B. Schwing, and E. L. Venrick (1995), The state of the California Current in 1994-1995: A period of transition, CalCOFI Rep. 36, pp. 19-39, La Jolla, Calif.

Henson, S. A., R. Sanders, C. Holeton, and J. T. Allen (2006a), Timing of nutrient depletion, diatom dominance and a lower-boundary estimate of export production for the Irminger Basin, North Atlantic, Mar. Ecol. Prog. Ser., 313, 73-84.

Henson, S. A., I. S. Robinson, J. T. Allen, and J. J. Waniek (2006b), Effect of meteorological conditions on interannual variability in timing and magnitude of the spring bloom in the Irminger Basin, North Atlantic, Deep Sea Res., Part I, 53(10), 1601-1615.

Hickey, B. M. (1998), Coastal oceanography of western North America from the tip of Baja California to Vancouver Island, in The Sea, vol. 11, edited by A. R. Robinson and K. H. Brink, pp. 345-393, John Wiley, Hoboken, N. J.

Hickey, B. M., S. Geier, N. Kachel, and A. F. MacFadyen (2005), A bidirectional river plume: The Columbia in summer, Cont. Shelf Res., 25(14), $1631-1656$

Husby, D. M., and C. S. Nelson (1982), Turbulence and vertical stability in the California Current, CalCOFI Rep. 23, pp. 113-129, La Jolla, Calif.

Huyer, A. (2003), Preface to special section on enhanced Subarctic influence in the California Current, 2002, Geophys. Res. Lett., 30(15), 8019 doi:10.1029/2003GL017724.

Huyer, A., R. L. Smith, and E. J. C. Sobey (1978), Seasonal differences in lowfrequency current fluctuations over Oregon continental shelf, J. Geophys. Res., 83(C10), 5077-5089.

Huyer, A., E. J. C. Sobey, and R. L. Smith (1979), Spring transition in currents over the Oregon continental shelf, J. Geophys. Res., 84(C11), 6995-7011.

Huyer, A., J. H. Fleischbein, J. Keister, P. M. Kosro, N. Perlin, R. L. Smith, and P. A. Wheeler (2005), Two coastal upwelling domains in the northern California Current system, J. Mar. Res., 63(5), 901-929.

Ikeda, M., and W. J. Emery (1984), Satellite observations and modeling of meanders in the California Current System off Oregon and northern California, J. Phys. Oceanogr., 14(9), 1434-1450.

Kaufman, L., and P. J. Rousseeuw (1990), Finding Groups in Data: An Introduction to Cluster Analysis, 342 pp., John Wiley, New York.

Kosro, P. M., W. T. Peterson, B. M. Hickey, R. K. Shearman, and S. D. Pierce (2006), Physical versus biological spring transition: 2005, Geophys. Res. Lett., 33, L22S03, doi:10.1029/2006GL027072.

Kraus, E. B., and J. S. Turner (1967), A one-dimensional model of the seasonal thermocline, Tellus, 19(1), 98-105.

Kudela, R. M., W. P. Cochlan, T. D. Peterson, and C. G. Trick (2006), Impacts on phytoplankton biomass and productivity in the Pacific Northwest during the warm ocean conditions of 2005, Geophys. Res. Lett., 33, L22S06, doi:10.1029/2006GL026772.

Kundu, P. K., J. S. Allen, and R. L. Smith (1975), Modal decomposition of velocity field near Oregon coast, J. Phys. Oceanogr., 5(4), 683-704.

Lalli, C. M., and T. M. Parsons (1997), Biological Oceanography: An Introduction, 314 pp., Elsevier, Oxford, U.K.

Legaard, K. R., and A. C. Thomas (2006), Spatial patterns in seasonal and interannual variability of chlorophyll and sea surface temperature in the California Current, J. Geophys. Res., 111, C06032, doi:10.1029/ 2005JC003282.

Lynn, R., et al. (1998), The state of the California current, 1997-1998: Transition to El Nino conditions, CalCOFI Rep. 39, pp. 25-49, La Jolla, Calif.

Lynn, R. J., S. J. Bograd, T. K. Chereskin, and A. Huyer (2003), Seasonal renewal of the California Current: The spring transition off California, J. Geophys. Res., 108(C8), 3279, doi:10.1029/2003JC001787.

MacFadyen, A., B. M. Hickey, and M. G. G. Foreman (2005), Transport of surface waters from the Juan de Fuca eddy region to the Washington coast, Cont. Shelf Res., 25(16), 2008-2021.

MacIsaac, J. J., R. C. Dugdale, R. T. Barber, D. Blasco, and T. T. Packard (1985), Primary production cycle in an upwelling center, Deep Sea Res. Part I, 32(5), 503-529.

Marchesiello, P., J. C. McWilliams, and A. Shchepetkin (2003), Equilibrium structure and dynamics of the California Current System, J. Phys. Oceanogr., 33(4), 753-783.

Millan-Nunez, R., S. Alvarez-Borrego, and C. C. Trees (1997), Modeling the vertical distribution of chlorophyll in the California Current System, J. Geophys. Res., 102(C4), 8587-8595.

Morel, A., and R. C. Smith (1974), Relation between total quanta and total energy for aquatic photosynthesis, Limnol. Oceanogr., 19(4), 591-600.

Morin, P., P. Le Corre, and J. Le Fevre (1985), Assimilation and regeneration of nutrients off the west coast of Brittany, J. Mar. Biol. Assoc. U. K. $65,677-695$.
Pierce, S. D., J. A. Barth, R. E. Thomas, and G. W. Fleisher (2006), Anomalously warm July 2005 in the northern California Current: Historical context and the significance of cumulative wind stress, Geophys. Res. Lett., 33, L22S04, doi:10.1029/2006GL027149.

Riley, G. A. (1957), Phytoplankton of the north central Sargasso Sea, Limnol. Oceanogr., 2(3), 252-270.

Schwing, F. B., N. A. Bond, S. J. Bograd, T. Mitchell, M. A. Alexander, and N. Mantua (2006), Delayed coastal upwelling along the U.S. West Coast in 2005: A historical perspective, Geophys. Res. Lett., 33, L22S01, doi:10.1029/2006GL026911.

Service, S. K., J. A. Rice, and F. P. Chavez (1998), Relationship between physical and biological variables during the upwelling period in Monterey Bay, CA, Deep Sea Res., Part II, 45(8-9), 1669-1685.

Sharples, J. (1999), Investigating the seasonal vertical structure of phytoplankton in shelf seas, Mar. Models Online, 1(1), 3-38.

Siegel, D. A., S. C. Doney, and J. A. Yoder (2002), The North Atlantic spring phytoplankton bloom and Sverdrup's critical depth hypothesis, Science, 296(5568), 730-733.

Small, L. F., and D. W. Menzies (1981), Patterns of primary productivity and biomass in a coastal upwelling region, Deep Sea Res., Part I, 28(2), $123-149$.

Smith, R. C., X. Y. Zhang, and J. Michaelsen (1988), Variability of pigment biomass in the California Current System as determined by satellite imagery: 1. Spatial variability, J. Geophys. Res., 93(D9), 10,863-10,882.

Soto-Mardones, L., A. Pares-Sierra, J. Garcia, R. Durazo, and S. Hormazabal (2004), Analysis of the mesoscale structure in the IMECOCAL region (off Baja California) from hydrographic, ADCP and altimetry data, Deep Sea Res., Part II, 51(6-9), 785-798

Strub, P. T., and C. James (1988), Atmospheric conditions during the spring and fall transitions in the coastal ocean off western United States, J. Geophys. Res., 93(C12), 15,561-15,584.

Strub, P. T., and C. James (2000), Altimeter-derived variability of surface velocities in the California Current System: 2. Seasonal circulation and eddy statistics, Deep Sea Res., Part II, 47(5-6), 831-870.

Strub, P. T., J. S. Allen, A. Huyer, and R. L. Smith (1987a), Large-scale structure of the spring transition in the coastal ocean off western North America, J. Geophys. Res., 92(C2), 1527-1544.

Strub, P. T., J. S. Allen, A. Huyer, R. L. Smith, and R. C. Beardsley (1987b), Seasonal cycles of currents, temperatures, winds, and sea level over the northeast Pacific continental shelf 35 to 48 degrees north, J. Geophys. Res., 92(C2), 1507-1526.

Strub, P. T., C. James, A. C. Thomas, and M. R. Abbott (1990), Seasonal and nonseasonal variability of satellite-derived surface pigment concentration in the California Current, J. Geophys. Res., 95(C8), 11,50111,530 .

Sverdrup, H. U. (1953), On conditions for the vernal blooming of phytoplankton, J. Cons. Cons. Perm. Int. Explor. Mer, 18, 287-295.

Sydeman, W. J., R. W. Bradley, P. Warzybok, C. L. Abraham, J. Jahncke, K. D. Hyrenbach, V. Kousky, J. M. Hipfner, and M. D. Ohman (2006), Planktivorous auklet Ptychoramphus aleuticus responses to ocean climate, 2005: Unusual atmospheric blocking?, Geophys. Res. Lett., 33, L22S09, doi:10.1029/2006GL026736.

Thomas, A. C., and P. Brickley (2006), Satellite measurements of chlorophyll distribution during spring 2005 in the California Current, Geophys Res. Lett., 33, L22S05, doi:10.1029/2006GL026588.

Thomas, A. C., and P. T. Strub (1989), Interannual variability in phytoplankton pigment distribution during the spring transition along the westcoast of North America, J. Geophys. Res., 94(C12), 18,095-18,117.

Thomas, A. C., and P. T. Strub (2001), Cross-shelf phytoplankton pigment variability in the California Current, Cont. Shelf Res., 21(11-12), 11571190.

Thomas, A. C., and R. A. Weatherbee (2006), Satellite-measured temporal variability of the Columbia River plume, Remote Sens. Environ., 100(2), $167-178$.

Thomas, A. C., F. Huang, P. T. Strub, and C. James (1994), Comparison of the seasonal and interannual variability of phytoplankton pigment concentrations in the Peru and California Current systems, J. Geophys. Res., 99(C4), 7355-7370.

Thomas, A. C., M.-E. Carr, and P. T. Strub (2001), Chlorophyll variability in eastern boundary currents, Geophys. Res. Lett., 28(18), 3421-3424.

Waniek, J. J. (2003), The role of physical forcing in initiation of spring blooms in the northeast Atlantic, J. Mar. Syst., 39(1-2), 57-82.

Wetz, M. S., P. A. Wheeler, and R. M. Letelier (2004), Light-induced growth of phytoplankton collected during the winter from the benthic boundary layer off Oregon, USA, Mar. Ecol. Prog. Ser., 280, 95-104.

S. A. Henson and A. C. Thomas, School of Marine Sciences, Aubert Hall, University of Maine, Orono, ME 04469, USA. (stephanie.henson@ umit.maine.edu) 